\title{
METODE DAKWAH IRSYAD UMAR BIN KHATTAB DALAM PERSPEKTIF SEJARAH
}

\author{
Patmawati dan Fitri Sukmawati \\ Institut Agama Islam Negeri (IAIN) Pontianak \\ Email: fwati1974@gmail.com
}

\begin{abstract}
The Irshad da'wah method is one of the methods of da'wah. This method was used by Umar bin Khattab as Amir al-mu'minin. At the time there was a massive futuhat, Muslims were not only from the Arabian Peninsula but also from Persia, Iraq, Iran and others, to preach to them, the method was very important in the success of da'wah. This paper uses the work of historical research, with the source of written documents. The results of the study explained that the method of Irsyad Umar bin Khattab's da'wah was divided into four namely irsyad nafsi, irsyad family, irsyad administration, and irsyad society.

(Metode dakwah irsyad merupakan salah satu metode dakwah. Metode ini dipakai oleh Umar bin Khattab sebagai Amirul Mukminin. Pada masanya terjadi futuhat secara besar-besaran, umat Islam tidak hanya dari penduduk Jazirah Arab tetapi juga dari daerah Persia, Irak, Iran dan lainlain, untuk berdakwah kepada mereka, metode sangat berperan penting dalam keberhasilan dakwah. Tulisan ini menggunakan cara kerja penelitian sejarah, dengan sumber dokumendokumen tertulis. Hasil dari penelitian menjelaskan bahwa metode dakwah irsyad Umar bin Khattab terbagi menjadi empat yakni irsyad nafsi, irsyad keluarga, irsyad pejabat, dan irsyad masyarakat).
\end{abstract}

Keywords: $n a f s i$, keluarga, pejabat, masyarakat.

\section{PENDAHULUAN}

Sejak turunnya surat al-Mudatssir pada tahun ketiga kenabian sekitar tahun 613 M. yang berbunyi, "Bangkitlah dan sampaikan peringatan ini”. Ini menandakan bahwa Islam adalah agama dakwah, dimana gagasan agama harus diaktualisasikan dalam kehidupan sosial dan politik (Lapidus, 1999: 34). Sebagai agama dakwah juga mengandung makna sebuah agama yang mendorong pemeluknya senantiasa aktif melakukan kegiatan dakwah (Suparta dan Harjani Hefni, 2009: 4).

Kegiatan dakwah baik yang dilakukan secara individu maupun kelompok (lembaga-lembaga dakwah) untuk mengajak umat manusia masuk ke dalam jalan Allah (kepada sistem Islam) dalam semua segi kehidupan sehingga Islam terwujud dalam kehidupan fardiyah, usrah, jamaah dan ummah. Akhirnya lahirlah tatanan khaira 
Patmawati dan Fitri Sukmawati

Metode Dakwah Irsyad Umar bin Khattab dalam Perspektif Sejarah

ummah dalam kehidupan masyarakat (Suneth dan Syafruddin Djosan, 2000: 8).

Dakwah islamiah sebagai sebuah kegiatan dakwah otomatis tidak terlepas dari metode atau cara, bagaimana tema dakwah dapat disampaikan dan diterima, dihayati serta diamalkan oleh umat. Penerapan metode dakwah bersifat kondisional dan variatif. Maksudnya dakwah yang dilakukan di suatu tempat belum tentu sama di tempat yang lain (Patmawati, 2014: 2), bahkan penerapan metode yang sama tetapi berbeda lokasi bisa melahirkan respon yang berbeda dari mad'u, oleh karena itu dapat dikatakan bahwa tidak ada metode dakwah yang dianggap paling tepat yang bisa diterapkan pada berbagai obyek dakwah (Cucu, 2013: 90).

Metode dakwah menurut Syukriadi Sambas dalam Cucu (2013: 89) adalah "sesuatu" yang menghubungkan pesan antara dai dengan mad'unya, yang secara hakikat berupa gerak dari instrument yang ada dalam diri dai berupa aktivitas lisan dan badan. Lisan disimbolkan dengan bahasa sedangkan badan adalah akhlak dan perilaku dai itu sendiri.

Irsyad atau konseling menurut Nurihsan dalam Kurnanto (2015: 3) sebuah upaya yang dilakukan untuk membantu individu melalui proses interaksi yang bersifat pribadi antara konselor dan konseli agar konseli mampu memahami diri dan lingkungannya, mampu membuat keputusan dan menentukan tujuan berdasarkan nilai yang diyakininya sehingga konseli merasa bahagia dan efektif perilakunya. Sedangkan irsyad Islam adalah proses penyampaian dan internalisasi ajaran Islam melalui kegiatan bimbingan, penyuluhan dan psikoterapi islami dengan sasaran individu atau kelompok kecil. Irsyad dimulai dengan kegiatan ibda' bi al-nafs: dzikr al-llah, do'a, tazkiyayyah al-nafs, shalat dan shaum (Enjang As dan Aliyudin, 2009: 60).

Dalam kajian ini akan menitikberatkan pada metode dakwah irsyad Umar bin Khattab karena dia adalah sosok khalifah yang tidak pernah kering untuk dibahas dari sudut manapun, mulai dari strategi komunikasi, pengorganisasian, peradaban yang dihasilkannya melalui futuhat dan membawa Madinah menjadi negara adi kuasa setelah menaklukkan wilayah kekuasaan Persia dan Romawi (Supriyadi, 2016: 82) dan lain-lain. Keberhasilan futuhat yang dilakukan oleh Umar bin Khattab diakui oleh Thomas Arnold dalam Ilaihi dan Harjani Hefni (2015: 79) sebagai berikut:

"Di banyak tempat, tidak jarang ditemukan penduduk negeri yang akan 


\section{Al-Hikmah: Jurnal Dakwah, Volume 12, Nomor 2, Tahun 2018 \\ [P. 195-210]}

dikuasai oleh Islam memuluskan jalan masuknya kaum muslimin ke negeri mereka. hal ini diakui secara jujur oleh para orientalis. Sebenarnya tidak terlalu salah jika ada tulisan yang mengatakan bahwa Islam disebarkan dengan pedang, karena memang di antara senjata yang digunakan untuk melakukan futuhat adalah pedang, tetapi ungkapan itu belum selesai. Pedang Islam saat itu hanya menebas leher orang-orang yang memilih perang dan berniat jahat kepada kaum muslimin. Sedangkan orangorang lemah, wanita, anak-anak dan orangorang yang telah menyerah kalah tidak disentuh oleh pedang Islam. Dan yang lebih penting untuk menjadi catatan kita adalah tersebarnya Islam tidak hanya dengan pedang, tetapi keindahan ajaran Islam yang disertai perlakuan ramah, adil, dan komitmen pemimpin dan rakyatnya melaksanakan ajaran Islam jauh lebih banyak mengislamkan masyarakat dunia".

Keindahan ajaran Islam yang disampaikan melalui dakwah yang bersifat universal dan luhur. Di mana para pemimpin Islam dan pengikutnya memperlihatkan sikap bersatunya akidah dan nalar. Dakwah Islam tidak tersekat oleh batasan etnis, warna kulit dan segala bentuk sudut pandang materi. Dengan futuhat kaum muslim tidak hanya menyebarkan Islam di wilayah Jazirah Arab saja, tetapi mereka tersebar ke seluruh penjuru bumi. Mereka berhasil membentangkan kekuasaan negara Islam setelah menumbangkan Romawi dan Persia. Mereka berhasil menghentikan kesewenangwenangan dua kerajaan tersebut. Sehingga, Islam dan kedamaian telah berhasil menguasai seperempat dari alam semesta ini (Mahasnah, 2016: 26).

Metode dakwah irsyad Umar bin Khattab belum penulis temukan pada tulisan-tulisan yang lain padahal dalam kehidupan Umar bin Khattab irsyad adalah sesuatu yang sering dilakukannya. Mulai dari irsyad nafsi, irsyad keluarga, irsyad pejabat dan irsyad masyarakat.

1. Metodologi Penelitian

Metode yang dipakai dalam kajian ini adalah metode sejarah. Menurut Alfian dalam Basri (2006: 14) penelitian sejarah menempuh langkahlangkah berikut: heuristic (mencari, menemukan dan mengumpulkan buktibukti sejarah), kritik (menguji dan menilai otensitas dan kredibilitas suatu bukti sejarah), auffasung (memahami makna atau sintesis fakta yang diperoleh melalui kritik sumber) dan desterllung 


\section{Patmawati dan Fitri Sukmawati}

\section{Metode Dakwah Irsyad Umar bin Khattab dalam Perspektif Sejarah}

(penulisan cerita sejarah atau penyajian dalam bentuk tertulis).

Pengumpulan data melalui dokumen-dokumen atau tulisan-tulisan mengenai Umar bin Khattab khususnya setelah Umar terpilih menjadi khalifah atau dikenal dengan istilah amirul mukminin (Sunanto, 2007: 23) dan (AlUsairy, 2003: 164). Irsyad nafsi dapat disaksikan di saat Umar membawakan pidato politiknya setelah dibaiat oleh kaum muslim di mesjid Nabawi Madinah. Penulisan sebagai tahap akhir dari prosedur penelitian sejarah ini diusahakan selalu memperhatikan aspek kronologis, sedangkan penyajiannya berdasarkan teme-tema mulai dari metode dakwah irsyad nafsi, irsyad keluarga, irsyad pejabat dan irsyad masyarakat.

Penulisan sejarah Umar bin Khattab ini akan dipaparkan dalam bentuk sejarah modern. Hal ini dimaksudkan bahwa peneliti tidak hanya menuliskan peristiwa sejarah, tetapi juga melakukan interpretasi atau tafsiran terhadap peristiwa sejarah tersebut. Penelitian ini tidak cukup hanya mengandalkan pendekatan sejarah, untuk melengkapinya peneliti menggunakan pendekatan sosiologi agama dan antropologi. Dengan demikian, pendekatan yang digunakan dalam kajian ini lebih bersifat pendekatan interdisipliner.

\section{HASIL DAN PEMBAHASAN}

Metode Dakwah Irsyad Nafsi Umar bin Khattab

Irsyad nafsi adalah suatu metode dakwah dimana konseli dan konselor menyatu dalam diri dai atau dengan kata lain dai dan mad'u itu menyatu dalam diri seseorang. Jadi, seorang dai sebelum membimbing seseorang melakukan suatu tindakan yang baik terlebih dahulu, dia telah melakukan perbuatan baik tersebut. Seorang muslim yang baik adalah bersatunya kata dan perbuatan. Al-Qur'an memberi label kaburamaktan bagi siapa saja yang berbicara tanpa melakukannya terlebih dahulu, sebagaimana dalam QS. Ash Shaf ayat 3: "Amat besar kebencian di sisi Allah, karena kamu mengatakan sesuatu yang tidak kamu perbuat".

Seorang dai memulai dari diri sendiri sehingga di saat dia memberi bimbingan ke orang lain, auranya akan terpancar dan membuat seseorang mengikuti apa yang diperintahkan. Hal ini sejalan dengan pendapat A. Hasjmy dalam Amin (2009: 3) yang mengatakan: 


\section{Al-Hikmah: Jurnal Dakwah, Volume 12, Nomor 2, Tahun 2018 \\ [P. 195-210]}

"Dakwah Islamiyah yaitu mengajak orang lain untuk meyakini dan mengamalkan aqidah dan syariah Islamiyah yang terlebih dahulu telah diyakini dan diamalkan oleh pendakwah sendiri".

Kwalitas pribadi sangat diperhatikan dalam Islam sebagaimana firman Allah dalam QS At-Tahrim ayat 6:

"Hai orang-orang yang beriman peliharakanlah dirimu dan keluargamu daripada neraka, yang bahan bakarnya manusia dan batubatu, sedang penjaganya malaikatmalaikat yang kasar lagi keras, mereka tiada mendurhakai Allah tentang apa-apa yang disuruhNya dan mereka memperbuat apa yang diperintahkan kepadanya".

Dalam pidato pengangkatan Umar bin Khattab sebagai khalifah, dia telah melakukan irsyad nafsi sebagaimana tercantum dalam doa yang dipanjatkan kepada Allah sebagai berikut:

"Ya Allah, aku ini lemah, maka kuatkanlah aku.

"Ya Allah, aku ini keras, maka lembutkanlah aku”.
"Ya Allah, aku ini kikir, maka jadikanlah aku pemurah" (Umairah, 2002: 30).

Dari doa ini Umar menyadari bahwa dia sebagai manusia biasa tidak terlepas dari kelemahan, kekerasan dan kebahilan. Untuk meminimalisir ketiga sifatnya dia memohon kepada Yang Kuasa supaya sifat yang tidak terpuji ini bisa terkikis dari diri Umar. Sehingga yang tampil adalah Umar sebagai sosok pemimpin yang disegani dan ditakuti tetapi bukan tirani.

Keberhasilan Umar bin Khattab dalam melakukan Futuhat sehingga wilayah Islam sudah dapat dibagi menjadi 8 provinsi yakni, Makkah, Madinah, Syriah, Jazirah, Basrah, Kufah, Palestina dan Mesir (Aizid, 2018: 572) mengakibatkan pajak yang begitu banyak yang mengalir ke pemerintahan Islam. Baitul Maal mampu menyediakan jaminan sosial kepada seluruh masyarakat mulai dari bayi yang masih menyusui sampai lansia tanpa membedakan agama. Kemakmuran negaranya tidak disertai dengan sikap foya-foya yang dilakukan para pejabat negara karena Umar bin Khattab sangat menghargai kesederhanaan dan mencela sifat mubassir. Umar bisa saja menggunakan harta Baitul 
Patmawati dan Fitri Sukmawati

Metode Dakwah Irsyad Umar bin Khattab dalam Perspektif Sejarah

Maal sebagai pemegang kunci, tetapi Umar selalu mampu manaklukkan dirinya dengan kesucian jiwanya (Al-Akkad, 1978: 71). Sehingga dia tidak pernah tergoda untuk memboros-boroskan harta Baitul Maal.

$$
\text { Al-Minsyawi (2004: }
$$

menceritakan bahwa suatu hari, istri Umar bin Khattab membawa sebungkus minyak samin (makanan enak) yang dia beli dengan harga 60 dirham, makanan itu akan diberikan ke Umar. Setelah Umar melihat bungkusan itu, dia bertanya, "Apakah itu?" istrinya menjawab "Samin. Aku membelinya dengan uangku sendiri, bukan dari nafkah yang engkau berikan kepadaku." Lalu Umar berkata, "Aku tidak akan mencicipinya sampai orang lain kenyang terlebih dahulu."

Larangan Umar terhadap para pejabatnya untuk tidak makan makanan pilihan (mewah) sudah dipraktekkan terlebih dahulu untuk mendisiplinkan dirinya dari makanan yang dilarangnya. Makanan yang disediakan oleh dapur umum lebih enak daripada makanan yang disantap Umar yang terdiri dari roti kering dan minyak. Umar benar-benar menjaga dan membatasi diri dengan tabah dan gigih untuk tidak menikmati lebih dari kebutuhannya, sikap inilah yang sulit ditiru oleh pemimpinpeminpin lainnya.
Pada masa paceklik atau dikenal dengan tahun Ramadah (Abu) dimana bumi menghitam seperti abu karena hujan tak kunjung turun. Umar ikut merasakan penderitaan rakyatnya. Sepanjang tahun dia tidak makan daging dan makanan berlemak, sehingga mukanya pucat dan lebam (Haekal, 2011: 605). Umar tak makan sebelum semua rakyatnya menerima pembagian dana sosial makanan. Sikap Umar telah memberi pelajaran terhadap para penguasa dunia secara khusus dan kemanusiaan secara umum mengenai amanat dan perhatian terhadap masyarakat (As-Suhaibani, 2016: 20).

Umar bin Khattab sebagai Amirul Mukminin sebenarnya memiliki hak untuk menggunakan harta Baitul Maal, tetapi Umar berpendapat bahwa Baitul Maal adalah harta kaum muslimin, dan dia adalah penjaga harta tersebut, seperti penjagaan seorang wali terhadap harta anak yatim. Apabila Umar fakir maka dia akan mengambil harta seperlunya sesuai dengan kebutuhannya. Umar hanya memiliki tiga buah baju, satu dipakai pada musim dingin dan satunya lagi dipakai pada musim panas, serta pakaian untuk berhaji dan umrah.

Di saat wilayah Syam ditaklukkan, Umar mendatangi wilayah tersebut. Dia disambut dengan kuda Bardum, namun 


\section{Al-Hikmah: Jurnal Dakwah, Volume 12, Nomor 2, Tahun 2018 \\ [P. 195-210]}

Umar menolak menungganginya. Dia masuk ke Syam dengan sikap tawadu', tidak menunjukkan kebanggan sebagai pemenang. Karena futuhat dilakukan hanya dalam rangka menyiarkan agama Islam dan penguasa sekitar yakni Persia dan Romawi tidak lagi mengancam eksistensi Islam. Oleh karena itu, dakwah melalui politik sangat dibutuhkan dalam rangka memakmurkan ajaran Islam dipermukaan bumi Allah.

Jika Umar melakukan suatu ucapan atau tindakan, maka rakyat diberi ruang untuk mengoreksi ucapan dan tindakannya tersebut tanpa melihat jenis kelamin, suku dan agama pengoreksinya. Hal ini bisa dilihat, saat Umar melarang kaum laki-laki memberikan mahar yang banyak kepada calon pengantin perempuan. pendapatnya ini disanggah oleh seorang perempuan dengan mengajukan sebuah pertanyaan: "Wahai Amirul Mukminin, apakah saya harus taat kepada Kitabullah atau kepada Amirul Mukminin?" Umar menjawab, "Kitabullah". Kalau begitu kenapa kamu melarang kami mengikuti firman Allah dalam QS An-Nisa' ayat 20:

"Jika kamu hendak menukar perempuan dengan perempuan yang lain, dan telah kamu berikan kepadanya harta yang banyak (mas kawin), janganlah kamu ambil kembali daripadanya sedikitpun. Adakah patut kamu ambil kembali harta itu dengan aniaya dan dosa yang terang".

Setelah dialog tersebut, Umar mengakui kesalahannya, dan mengakui pendapat perempuan itulah yang benar. Umar sosok yang sangat keras tetapi rakyat tidak segang melakukan sanggahan terhadap pendapatnya. Seorang budak sekalipun bebas berkomunikasi dengan Umar, seperti yang dilakukan Abu Lu'luah budak Mughirah, dimana dia memprotes Umar terhadap kebijakan pajak diri yang dia rasa terlalu tinggi.

Pada saat rakyat melakukan protes melalui tindakan, seperti yang dilakukan Muhammad bin Maslamah di saat dia masuk kedalam masjid, dia mengeraskan suara takbir dan mengatakan, "benar Allah dan Rasulnya". Dia mengulangi kalimat tersebut lewat pembesar suara. Umar yang mendengar suara takbir dan kalimat yang diungkapkan Muhammad bin Maslamah, mengirim utusan supaya Muhammad bin Maslamah menemuinya. Muhammad bin Maslamah menjawab, "saya akan menemui Umar tetapi saya shalat dua rakaat terlebih dahulu". Akhirnya Umar lah yang menemui 
Patmawati dan Fitri Sukmawati

Metode Dakwah Irsyad Umar bin Khattab dalam Perspektif Sejarah

Muhammad bin Maslamah di mesjid dan menunggu sampai dia menyelesaikan sembahyangnya. Akhirnya Umar menanyakan tindakan Muhammad bin Maslamah, "Apa maksud tindakanmu tersebut/". Dia menjawab, "saya telah berpapasan dengan dua orang Quraisy yang mengenakan baju pemberian Amirul mukminin dan seorang Anshar yang mengenakan baju yang pendek (tidak sampai mata kaki seperti kedua baju orang Quraisy) juga pemberian Amirul mukminin, saya teringat sabda Rasulullah yang mengatakan, "Ketahuilah, kalian akan menemui perlakuan pilih kasih sepeninggalku". Wahai Amirul Mukminin saya tidak mau sabda Rasulullah itu terjadi pada masamu. Mendengar penjelasan itu Umar menangis dan memohon ampun kepada Allah. setelah kejadian ini orangorang Quraisypun tidak lebih lagi dibanding dengan orang-orang Anshar (AlKandahlawi, 2004: 205-206).

Keberanian rakyat dalam memberi masukan kepada Amirul Mukminin menandakan bahwa sistem pemerintahan tidak kaku tetapi menerima masukan dari mana saja. Hal ini yang menyebabkan Umar mampu mengantarkan wilayah kekuasaan Islam pada puncaknya. Muncul pemerintahan yang sehat dan membuat negara menjadi kokoh karena semua rakyat merasa memiliki dan berkepentingan dengan keberadaan negara. Mereka menjadi rakyat yang berani bukan masyarakat bisu. Salah satu yang membuat rusak sebuah wilayah apabila rakyat sudah tak mau memberi nasehat kepada pemimpinnya. Dalam naskah kuno Lontara Attorioloang ri Wajo disebutkan mataukki mappangaja' ri arungnge yang berarti takut memberi nasehat atau mengingatkan suatu kesalahan kepada Arung (pemerintah) (Patmawati dan Besse Wahida, 2017: 879).

Metode Dakwah Irsyad Keluarga Umar bin Khattab

Filosof Muhammad Iqbal (1953: 44) mengatakan: "emas, perak dan hasil negeri bukanlah kekayaan yang terutama dari suatu bangsa atau Negara. Kekayaan sejati dari suatu masyarakat atau bangsa ialah putra dan putrinya yang giat, bercita-cita tinggi, bekerja keras dan cepat menangkap dan menanggap sesuatu".

Keberadaan putra putri dalam keluarga, di mana orang tua menuntun dan mengesankan kepribadiannya terhadap anak. Orang tua memperlakukan hal yang sama terhadap putra putrinya, karena setiap anak dalam perspektif Islam lahir dalam keadaan suci, bagaikan kertas kosong, orang 


\section{Al-Hikmah: Jurnal Dakwah, Volume 12, Nomor 2, Tahun 2018 \\ [P. 195-210]}

tuanyalah yang mencetak anak itu akan menjadi apa. Orang tua berkewajiban mendidik putra putrinya menjadi anak yang saleh yakni berani melakukan kebenaran dan takut mengerjakan kesalahan. Hal ini bisa terwujud apabila orang tua mampu mentransferkan keilmuan dan kepribadian (ketaqwaan) kepada anak-anak mereka (Sukmawati dan Patmawati (2017: 882).

Keluarga sebagai komunitas terkecil dalam masyarakat memegang peran penting sebagai pendidik utama, sebagaimana diungkapkan oleh Elizabeth H. Brady dalam Haitami dikutip oleh Sukmawati dan Patmawati (2017: 302), ada dua unsur esensial dalam pendidikan anak, yaitu keterlibatan orang tua dalam pendidikan anak dan tingkat pendidikan orang tua itu sendiri. Keterlibatan orang tua lebih mendasar ketimbang orang lain, karena adanya kedekatan emosional dalam melakukan proses pendidikan dan pembinaan terhadap anak. Tingkat pendidikan orang tua juga merupakan hal yang sangat mendasar karena mendidik anak bukan sekedar proses alamiah, akan tetapi memerlukan ilmu dan manajemen yang baik.

Pendapat Elizabeth ini akan peneliti pakai dalam melihat pola pendidikan Umar bin Khattab terhadap keluarganya, dimana Umar selain sebagai pemimpin keluarga juga pemimpin umat (Amirul mukminin). Umar terkenal sebagai orang yang sangat keras tetapi menghormati pasangan (isteri) dan penuh kasih terhadap anak-anaknya.

Sikap hormat dan toleransi Umar terhadap isterinya dapat diketahui melalui kisah yang menuturkan bahwa pada suatu hari ada seorang laki-laki yang berdiri di depan pintu rumah Umar, isteri Umar menemui dan bertanya, "ada apa?", dia menjawab, "Saya ingin menemui Umar dan mengadukan sikap isteri saya yang sering mengomel". Istri Umar berkata: "Saya pun melakukan hal yang sama dengan isterimu". Akhirnya laki-laki itu pulang dan bergumam, jika Amirul Mukminin saja bisa toleran terhadap sikap isterinya maka saya juga harus bisa seperti itu.

Umar keluar dan memanggil lakilaki tersebut. Sang laki-laki menceritakan tujuan awal dan hasil pembicaraannya dengan isteri Umar. Akhirnya Umar menasehatinya dengan berkata: "Aku menanggung (omelannya) karena beberapa hal yang menjadi kewajibanku" (Umairah, 2002: 48).

Seorang isteri memiliki hak terhadap suaminya, dan seorang suami memiliki 
Patmawati dan Fitri Sukmawati

Metode Dakwah Irsyad Umar bin Khattab dalam Perspektif Sejarah

kewajiban terhadap isterinya. Sebagaimana QS. Ar-Rum ayat 21:

"Dan di antara tanda-tandaNya, bahwa Dia menciptakan jodoh untukmu dari dirimu (bangsamu), supaya kamu bersenang-senang kepadanya dan Dia mengadakan sesama kamu kasih sayang dan rahmat. Sesungguhnya tentang demikian itu, menjadi ayat (tanda) bagi kaum yang memikirkan".

Ayat di atas dipertegas dengan sabda Rasulullah saw: "Orang yang terbaik di antara kamu ialah yang paling baik kepada keluarganya (isterinya). Aku adalah yang paling baik kepada isteriku" (HR Ibnu Hibban dan Ibnu Majah).

Perhatian Umar terhadap keluarga dalam bentuk penuh kasih kepada anak isterinya, ditandakan dengan pembatalan pengangkatan seorang calon gebernur karena kurangnya rasa sayang terhadap anak-anaknya. Umar beranggapan kalau terhadap anaknya sendiri dia tidak penyayang apalagi terhadap rakyat (Umairah, 2002: 49).

Umar dalam melaksanakan irsyad keluarga, dapat dilihat sewaktu dia mengumpulkan keluarganya dan berkata:
"Aku telah melarang manusia melakukan anu dan anu. Manusia itu memandangmu bagaikan burung memandang daging. Jika kamu melakukannya, mereka pun akan melakukan. Jika kamu memulai, mereka pun memulai. Demi Allah, jika salah seorang di antara kamu melakukan apa yang telah aku larang, aku akan melipatgandakan hukumannya. Siapa di antara kamu yang berani, silahkan. Siapa yang mau, mundurlah" (Umairah, 2002: $50)$.

Umar sangat memperhatikan dan mengawasi gerak gerik kaumnya (Bani Ady), agar mereka tidak menyalahgunakan kesempatan karena jabatan Umar sebagai Amirul Mukminin. Dia tidak segang-segang menindak keluarganya sendiri jika dilihatnya ada gejala mengarah ke hal negatif (Akkad, 1978: 182).

Perkataan dan tindakan Umar ini dibuktikan saat anaknya sendiri yakni Abdurrahman bin Umar meminum khamar sampai mabuk. Kemudian dihukum oleh Amr bin Ash gebernur Mesir karena Abdurrahman bin Umar adalah rakyatnya. Setelah informasi sampai ke Umar, dia meminta Amr bin Ash mengirim anaknya ke Madinah dalam keadaan terantai, supaya 


\section{Al-Hikmah: Jurnal Dakwah, Volume 12, Nomor 2, Tahun 2018 \\ [P. 195-210]}

anaknya dan rakyat mengetahui keburukan anaknya. Hal ini dilakukan Umar, bukan dalam rangka pamer keadilan, tetapi memberitahukan rakyat bahwa hukum harus ditegakkan secara adil tanpa melihat siapa pelakunya (Rohim, 2017: 90). Perilaku Umar membuat pejabat dan rakyat tidak berani melanggar aturan Tuhan yang dijaga oleh Umar bin Khattab.

Metode Dakwah Irsyad Pejabat Umar bin Khattab

Kebijakan Umar bin Khattab sebagai Amirul Mukminin sangat menentukan kebangkitan dan perkembangan peradaban Islam dari masa ke masa. Umar sangat berani, tegas dalam bersikap, jujur dan berkeadilan dalam melihat setiap persoalan, baik menyangkut pribadi, keluarga, pejabat dan umat dari berbagai aspek kehidupan (Abbas, 2018). Dalam melahirkan sebuah kebijakan atau keputusan, Umar selalu mengajak para sahabat bermusyawarah, sehingga sahabat-sahabat dilarang meninggalkan Madinah karena merekalah anggota legislatif yang selalu dimintai oleh Umar saran dan pendapatnya terhadap persoalan yang dihadapi umat. Walaupun keputusan terakhir tetap berada di tangan Amirul Mukminin karena dialah yang bertanggung jawab terhadap Tuhan dan rakyat terhadap keputusan yang diambilnya.

Di saat Umar akan menunjuk calon gebernur, dia mengajak para sahabat bermusyawarah dengan melontarkan ungkapan sebagai berikut:

"Aku mengharapkan seseorang yang apabila ia berada pada suatu kaum, sedang dia bukan pemimpin mereka, maka dia seolah-olah pemimpin mereka. jika dia merupakan pemimpin mereka, dia seolah-olah merupakan bagian dari rakyatnya."

Para sahabat menjawab: "Orang yang bersifat demikian hanya kami temukan pada Ar-Rabi' bin Ziyad al-Haritsi” (Umairah, 2002: 32).

Pada masa Umar bin Khattab, dia telah menetapkan syarat-syarat menjadi pemimpin, yakni: tidak menunggangi kereta kuda, tidak memakai pakaian dari kain tipis, tidak menyantap makanan hasil pemilihan (yang terbaik kwalitasnya), dan tidak mengunci pintu rumah sehingga rakyat dapat menemui mereka.

Selain syarat-syarat pemimpin yang sudah ditetapkan di atas. Pejabat yang sudah ditunjuk oleh Umar akan dikirimi surat, dan surat ini tidak hanya diperuntukkan buat 


\section{Patmawati dan Fitri Sukmawati \\ Metode Dakwah Irsyad Umar bin Khattab dalam Perspektif Sejarah}

pejabat yang ditunjuk tetapi ditembuskan kepada para sahabat dari kalangan Muhajirin dan Anshar. Isi surat tersebut adalah bahwa pejabat yang ditunjuk tidak akan menzalimi seseorang, baik yang menyangkut harta maupun fisik. Dia sebagai pejabat tidak akan memanfaatkan jabatannya untuk suatu keuntungan atau kepentingan pribadi (golongannya).

Bagi para pejabat yang sudah dilantik dan akan diutus, Umar akan berkata:

"Aku tidak mengangkatmu untuk menumpahkan darah kaum muslimin serta menodai kehormatan dan harta mereka, tetapi supaya kamu menegakkan shalat di tengah-tengah mereka, bersikap proporsinal, dan menetapkan keputusan dengan adil”.

Selanjutnya Umar berkata:

"Aku tidak mengutusmu sebagai orang yang tiran, tetapi aku mengutusmu sebagai pemimpin. Janganlah kamu memukul kaum muslimin karena mereka akan melecehkanmu, janganlah meтuji mereka karena kamu akan diuji oleh mereka, dan jangan menolak permintaan mereka karena mereka akan berbuat zalim" (Umairah, 2002: 33).
Dalam masalah jizyah (pajak keamanan) dan tawanan, Umar bin Khattab selaku Amirul Mukminin lebih mengutamakan kedamaian dan dakwah. Hal ini dapat dilihat melalui surat yang dikirim kepada Amr bin Ash:

“Amma ba'du....

Telah datang suratmu yang memberitahukan bahwa penguasa kota Iskandariyah menawarkan untuk member kamu jizyah dengan syarat kamu harus membebaskan seluruh tawanan dari negerinya. Maka demi Allah! Harta jizyah yang terus menerus kita peroleh dan diperoleh juga oleh kaum muslimin setelah kita itu lebih aku sukai daripada fai (harta rampasan perang) yang sebentar kemudian habis dibagi-bagikan. Katakana pada penguasa kota Iskandariah bahwa dia bias membayar jizyah padamu dengan syarat para tawanan yang ada dalam kekuasaan kalian itu diberi kebebasan untuk memilih masuk Islam atau ingin tetap dalam agama mereka. Barangsiapa yang bersedia masuk Islam, maka dia mempunyai hak dan kewajiban yang sama seperti orang Islam yang lainnya. Dan barangsiapa yang memilih tetap dalam agama mereka, maka mereka harus membayar jizyah seperti yang 


\section{Al-Hikmah: Jurnal Dakwah, Volume 12, Nomor 2, Tahun 2018 \\ [P. 195-210]}

telah ditetapkan atas pemeluk agamanya...." (Al-Kandahlawi, 2003: 333-334).

Metode Dakwah Irsyad Masyarakat Umar bin Khattab

Irsyad terhadap masyarakat merupakan hal pertama yang dilakukan Umar sebagai Amirul Mukminin. Hal ini dapat dilihat dalam pidato politik Umar, setelah dia memanjatkan doa kepada Allah, dia berkata:

"Sesungguhnya Allah menguji kalian dengan saya dan menguji saya dengan kalian; dan membiarkan saya memimpin kalian sesudah sahabat saya (Abu Bakar). Oleh karena itu, demi Allah, apabila ada urusan yang dihadapkan kepada saya, biarlah urusan itu hanya diurus oleh saya; dan janganlah seseorang menjauhkan diri dari saya sehingga saya tidak dapat memilih orang yang benar dan memegang amanah. Jika mereka berbuat baik, tentu saya berbuat baik pada mereka; dan jika mereka berbuat jahat, tentu saja saya akan menghukum mereka" (Pulungan, 2018: 127).
Pidato di atas memperlihatkan pandangan Umar mengenai seluk beluk negara, di mana rakyat tidak hanya berperan sebagai pelengkap dari sebuah negara, tetapi keberadaan negara dan perangkatnya dalam rangka melayani masyarakatnya dengan memudahkan segala urusan mereka. para pejabat harus membuka pintu rumah mereka selebar-lebarnya sehingga masyarakat dapat menemui mereka kapan saja. Masyarakat yang lemah harus didekati sehingga mereka berani bicara apa saja, memperhatikan hak perantau, membina kerukunan antar manusia, serta mendamaikan orang atau kelompok yang bertikai.

Umar selalu berkata kepada rakyat, bahwa dia mengangkat pejabat dalam hal ini gebernur sebagai penguasa di sebuah provinsi bukan untuk menindas dan mengambil harta rakyat. Gebernur dilantik dalam rangka mendidik, mengajari rakyat tentang masalah agama dan sunnah Nabi serta melayani masyarakat. Apabila terdapat gebernur yang melakukan penganiayaan terhadap rakyat, rakyat bebas mengadukan perbuatan gebernur tersebut kepada Amirul Mukmini.

Perkataan Umar ini pernah disanggah oleh Amr bin Ash, dia berkata, "Hai Amirul Mukminin, bagaimana jika 
Patmawati dan Fitri Sukmawati

Metode Dakwah Irsyad Umar bin Khattab dalam Perspektif Sejarah

seorang muslim menjadi gebernur atas rakyatnya, lalu dia mendidik sebagian mereka, apakah engkau akan menuntut qisahs pula?"

Umar menjawab:

"Demi Zat yang menguasai diriku, sungguh akan menuntutnya. Aku pernah melihat Rasulullah saw mengqisash dirinya sendiri. Ketahuilah, janganlah kamu memukul kaum muslimin karena mereka akan menghinamu, janganlah kamu menolak hak-hak mereka karena mereka akan menginkarimu, janganlah kamu berbaur larut dengan mereka karena mereka akan melecehkanmu." (Umairah, 2002: 33-34).

Setelah Umar memberi jawaban, salah satu khalayak berdiri dan berkata, "gebernurku telah memukulku sebanyak 100 kali dera". Umar berkata, "silahkan laksanakan qisash terhadap gebernur tersebut", qisash ini akhirnya dibayat dengan 1 dera sebanyak 2 dinar dengan kerelaan dari yang bersangkutan.

Kebijakan Umar tidak hanya dirasakan dan dinikmati oleh kaum muslimin, tetapi penganut agama lain juga merasakan nikmatnya kebijakan Amirul mukmini. Hal ini dapat dilihat dalam naskah surat yang dikirim Umar kepada penduduk Iliyah, penganut agama Nasrani. Isi surat tersebut antara lain sebagai berikut:

"Dari seorang hamba Allah, Amirul Mukminin Umar kepada penduduk kota Iliyah, memberikan jaminan keamanan terhadap diri mereka, keluarga, harta benda, gereja-gereja dan salib-salib yang mereka miliki. Demikian juga terhadap orangorang yang sehat maupun sakit serta semua yang mengikuti agama mereka tidak akan disita atau dirobohkan. Semua harta benda maupun isi yang terdapat di dalamnya tidak akan diambil. Tidak ada seorang pun dari mereka yang ditekan atau diganggu..."(Al-Akkad, 1978: 91).

Surat Umar ini apabila ditelisik dari segi isi, tidak jauh berbeda dengan "Piagam Madinah" yang lahir pada masa Nabi. Mereka diberi kebebasan dan penghormatan menjalankan agama. Dalam beragama tidak ada paksaan, manusia bebas beragama, hanya kebebasanlah yang bisa mengantarkan kepada kesadaran beragama.

\section{KESIMPULAN}




\section{Al-Hikmah: Jurnal Dakwah, Volume 12, Nomor 2, Tahun 2018 \\ [P. 195-210]}

Umar bin Khattab sebagai Amirul Mukminin telah melakukan futuhat sehingga dia dianggap sebagai pembangun peradaban Islam. Umar sosok pemimpin sekaligus dai yang sangat berhasil dalam menjalankan tugasnya, keberhasilan yang dicapai terwujud berkat bersatunya kata dan perbuatan. Metode dakwah irsyad Umar bin Khattab dibagi menjadi empat yakni, irsyad nafsi, irsyad keluarga, irsyad pejabat dan irsyad masyarakat.

\section{DAFTAR PUSTAKA}

Abbas, Nurlaelah, 2018, "Strategi Komunikasi Di Masa Umar bin Khattab", dalam jurnal Jurnalisa vol 04 Nomor 1, Mei.

Aizid, Rizem, 2018, Sejarah Terlengkap Peradaban Dunia Dari Masa Sebelum Masehi Hingga Modern, Yogyakarta: Noktah.

Al-Akkad, Abbas Mahmoud, 1978, Abqariyyatu Umar, diterjemahkan oleh H. Bustami A. Gani dan Zainal Abidin Ahmad, dengan judul "Kecemerlangan Khalifah Umar bin Khattab", Jakarta: Bulan Bintang.

Al-Kandahlawi, Muhammad Yusuf, 2003, Kehidupan Para Sahabat, Bandung: Pustaka Zaadul Ma'ad. 2004, Kisah-kisah Teladan Sahabat Nabi Episode Hijrah \&
Memberikan Pertolongan, Yogyakarta: Mitra Pustaka.

Al-Minsyawi, Muhammad Shadiq, 2004, 101 Kisah Umar bin Khattab, Jakarta: Cendekia Sentra Muslim.

Al-Usairy, Ahmad, 2003, Sejarah Islam Sejak Zaman Adam Hingga Abad XX, Jakarta: Akbar Media Eka Sarana.

Amin, Samsul Munir, 2009, Ilmu Dakwah, Jakarta: Amzah.

As-Suhaibani, Abdul Hamid, 2016, Para Sahabat Nabi Kisah Perjuangan, Pengorbanan, dan Keteladanan, Jakarta: Darul Haq.

Basri MS., 2006, Metodologi Penelitian Sejarah (Pendekatan, Teori dan Praktik), Jakarta: Restu Agung.

Cucu, 2013, Ilmu Dakwah, Pontianak: STAIN Press.

Enjang As dan Aliyuddin, 2009, Dasardasar Ilmu Dakwah Pendekatan Filosofis dan Praktis, Bandung: Widya Padjadjaran.

Haekal, Muhammad Husain, 2011, Sejarah Hidup Muhammad, Jakarta: Litera AntarNusa.

Ilaihi, Wahyu dan Harjani Hefni, 2015, Pengantar Sejarah Dakwah, Jakarta:

Kencana.

Iqbal, Muhammad, 1953, Rahasia-rahasia Pribadi, Djakarta: Pustaka Islam.

Kurnanto, M. Edi, 2015, Bimbingan dan Konseling Keagamaan, Pontianak: IAIN Press. 
Patmawati dan Fitri Sukmawati

Metode Dakwah Irsyad Umar bin Khattab dalam Perspektif Sejarah

Lapidus, Ira. M., 1999, Sejarah Sosial Umat Islam, Jakarta: Raja Grafindo Persada.

Mahasnah, Muhammad Husain, 2016, Pengantar Studi Sejarah Peradaban Islam, Jakarta: Pustaka Al-Kautsar.

Patmawati, 2014, "Sejarah Dakwah Rasulullah saw di Mekah dan Madinah", dalam Jurnal AlHikmah, Vol. VIII Edisi 2, Desember.

- dan Besse Wahidah, 2017, "Model Komunikasi Dalam Naskah Lontara Attorioloang ri Wajo" dalam Proceedings International Conference on Media Studies, di Universitas Utara Malaysia (UUM) di Kedah.

Pulungan, J. Suyuti, 2018, Sejarah Peradaban Islam, Jakarta: Amzah.

Rohim, Abdul, 2017, Jejak Langkah Umar bin Khattab Kisah Pemimpin Besar yang Sederhana dan Keras Dalam Kebenaran, Yogyakarta: Mueeza.

Sukmawati, Fitri dan Patmawati, 2017, "Mendidik Anak Secara Islam Dalam Usaha Mengembangkan Potensinya", dalam International Conference Proceeding Pengembangan Potensi Anak Usia Dini, Pontianak: Bulan Sabit Press.

Sunanto, Musyrifah, 2007, Sejarah Islam Klasik Perkembangan Ilmu Pengetahuan Islam, Jakarta: Kencana.

Suneth, A. Wahab dan Syafruddin Djosan, 2000, Problematika Dakwah
Dalam Era Indonesia Baru, Jakarta: Bina Rena Pariwara.

Suparta, Munzier dan Harjani Hefni, 2009, Metode Dakwah, Jakarta: Kencana.

Supriyadi, Dedi, 2016, Sejarah Peradaban Islam, Bandung: Pustaka Setia.

Umairah, Abdurrahman, 2002, Tokoh-tokoh yang Diabadikan Al-Qur'an, Jakarta: Gema Insani Press. 